\title{
Melatonin MT-1-receptor immunoreactivity in the human eye
}

\author{
P Meyer, M Pache, K U Loeffler, L Brydon, R Jockers, J Flammer, A Wirz-Justice, \\ E Savaskan
}

See end of article for

authors' affiliations

Br J Ophthalmol 2002;86:1053-1057

Correspondence to: Peter Meyer, MD, University Eye Clinic Department of

Ophthalmopathology, PO Box, CH-4012, Basel, Switzerland;

Peter.Meyer@unibas.ch

Accepted for publication 4 April 2002

\begin{abstract}
Aim: To examine the distribution of melatonin la (MT1) receptors in the human eye.
Methods: Seven normal human eyes were examined by immunohistochemical staining of paraffin sections, using an anti-MT1 primary antibody and an $A B C$ detection system.

Results: MT1 receptor immunoreactivity (MTI-IR) was detected primarily in the inner segments of rods and cones and in retinal ganglion cells. In addition, MTI-IR was present in the adventitia of retinal arteries and veins, including the papillary region, but absent in ciliary and choroidal vessels. Mild staining of corneal endothelial cells and keratocytes was observed in all but two eyes.

Conclusion: MT I-IR is present in various ocular tissues with the highest density in photoreceptor cells and ganglion cells. The physiological function of these receptors deserves further investigation.
\end{abstract}

M elatonin is synthesised in the pineal gland and in the retina in a diurnal rhythm with increased levels at night. Experimental studies suggest that retinal melatonin is synthesised in photoreceptor cells ${ }^{12}$ under the control of a circadian oscillator located within the retina itself. ${ }^{2}$

The function of melatonin in the human eye, however, is as yet only partially disclosed. In vertebrates, melatonin mediates dark adaptive regulation of retinomotor movements, ${ }^{3}$ circadian disc shedding in photoreceptor cells, ${ }^{4}$ regulation of horizontal cell sensitivity to light, ${ }^{5}$ and modulation of dopamine release. ${ }^{6}$ As in the pineal gland, retinal melatonin may also act as a signal of darkness. Furthermore, a role as a scavenger of free radicals within the photoreceptors has been proposed for melatonin.?

In mammals, the specific functions of melatonin are mediated by two different subtypes of $\mathrm{G}$ protein coupled receptors, the melatonin la (MT1) and melatonin lb (MT2) receptor. ${ }^{8}$ Meanwhile, specific polyclonal antibodies against MTl have become available, ${ }^{8}$ and MTl receptor expression has been studied in rodents using immunocytochemistry and in situ hybridisation. ${ }^{910}$

For a better understanding of the role of melatonin in the human eye, it is essential to determine its precise target cells. Therefore we examined the distribution of MTl receptors in normal human eyes by means of immunohistochemistry.

\section{MATERIALS AND METHODS}

\section{Tissue preparation}

Human tissue samples

Paraffin embedded human eyes, fixed in $4 \%$ paraformaldehyde, were obtained post mortem from seven patients without ophthalmological or neurological diseases $(\mathrm{M}: \mathrm{F}=1: 6$; mean age 81.7 years (SD 12.5). The cause of death was either heart failure or pneumonia in all cases. The sample collection was approved by the ethics committee criteria and followed the tenets of the Helsinki Declaration. Tissue samples were cut in a sagittal plane including the optic nerve head and pupil and $4 \mu \mathrm{m}$ thick serial sections were made with a microtome.

\section{Immunohistochemistry}

Sections were mounted on gelatine chromalum coated glass slides, and deparaffinised. The antigen was finally visualised by peroxidase staining using the peroxidase substrate 3 amino-9-ethylcarbazole (AEC), as previously reported. ${ }^{11}$ The optimum concentration of the primary antibody was previously determined to be $1: 100 .{ }^{12}$ The affinity purified polyclonal antibody used to specifically detect MTl was developed against the $\mathrm{C}$ terminus of the receptor and the antibody recognition of native MTl receptor has been ascertained. ${ }^{8}$ In addition, the antibody has been applied successfully in previous immunohistochemical experiments. ${ }^{12}$ To test the specificity of the primary antibody, control sections were stained simultaneously, following the same procedure with the exception that the primary antibody was omitted. Tissue of the hippocampus served as positive control. ${ }^{12}$ Moreover, we performed $\alpha$-smooth muscle actin staining in adjacent control sections using specific monoclonal antibodies (Monoclonal Anti- $\alpha$-Smooth Muscle Actin, Sigma Chemicals Co, St Louis, $\mathrm{MO}$, USA) to distinguish between the different layers of the vessel wall.

All sections were assessed for localisation and intensity of specific immunoreactivity on a semiquantitative scale of + to +++ by two blind observers (details are given in Tables $1-3$ ). In case of disagreement, consent was achieved by discussion.

\section{RESULTS \\ Ocular tissue}

Various cell types of cornea, retina, as well as retinal arteries and veins displayed specific MTl-IR. Serial control sections omitting the primary antibody revealed no immune reaction. $\alpha$-Smooth muscle actin staining was observed in the smooth muscle cells of the tunica media in all ocular vessels.

\section{Retina}

In the whole retina, some variation in intensity was observed, but specific immunoreactivity was seen in the following compartments (see also Table 1).

\section{Ganglion cells}

In all eyes, about $90 \%$ of ganglion cells revealed MTl-IR in their somata and dendritic processes. MTl staining varied between + to +++ in intensity and showed a fine granular homogeneous distribution in the perinuclear area (see Fig l). 
Table 1 Intensity of specific immunoreactivity on a semiquantitative scale of $+/+++$ for ganglion cells, amacrine cells, and photoreceptor cells

\begin{tabular}{|c|c|c|c|c|c|}
\hline Case No & Age (years) & $\begin{array}{l}\text { Time between death } \\
\text { and necropsy (hours) }\end{array}$ & Ganglion cells & Amacrine cells & $\begin{array}{l}\text { Photoreceptor cells } \\
\text { (rods > cones) }\end{array}$ \\
\hline 1 & 59 & 12.40 & $+-++(>90 \%)$ & - & +++ \\
\hline 2 & 97 & 06.10 & $+++(>90 \%)$ & $+(3-4)$ & +++ \\
\hline 3 & 88 & 31.45 & $++(>90 \%)$ & $+(8)$ & ++ \\
\hline 4 & 76 & 23.45 & $+++(>90 \%)$ & $+(6)$ & ++ \\
\hline 5 & 91 & 24.32 & ++ & $+(4 \times 2)$ & +++ \\
\hline 6 & 85 & 18.10 & +++ & $+(21)^{\prime}$ & +++ \\
\hline 7 & 35 & 14.45 & ++ & $+(5)$ & ++-+++ \\
\hline
\end{tabular}

Inner nuclear layer

In all but one case, single cells with MTl-IR were located in the inner nuclear layer (3-21 cells in the whole retina per section) (compare Fig 1).

\section{Photoreceptor cells}

All photoreceptor cells revealed distinct MTl-IR $(++$ to +++ in intensity) in their inner segments. Cell somata and outer segments appeared unlabelled. MTl-IR extended as an immunoreactive band throughout the complete photoreceptor cell layer (Fig 1).

In all cases, slight MT1 labelling of the inner plexiform layer was observed, whereas in the outer plexiform layer only weak immunoreactivity was present in four cases.

\section{Ocular vessels}

Central retinal vessels in the papillary region

Distinct MTI-IR in the adventitia of central retinal arteries and veins was observed in all cases $(++$ to +++ in intensity). No difference in the intensity of staining between the arteries and veins was found (see Fig 2, Table 2).

\section{Retinal vessels}

The same staining pattern as described for the central retinal vessels in the papillary region was also found in the adventitia of the small retinal vessels located in the ganglion cell layer and in the inner plexiform layer (compare Fig 2, Table 2).

\section{Choroidal and ciliary vessels}

In two of six cases, low levels of MTl-IR were observed in the choroidal vessels, mainly in the peripapillary region. Ciliary vessels were not labelled (see Table 2 ).
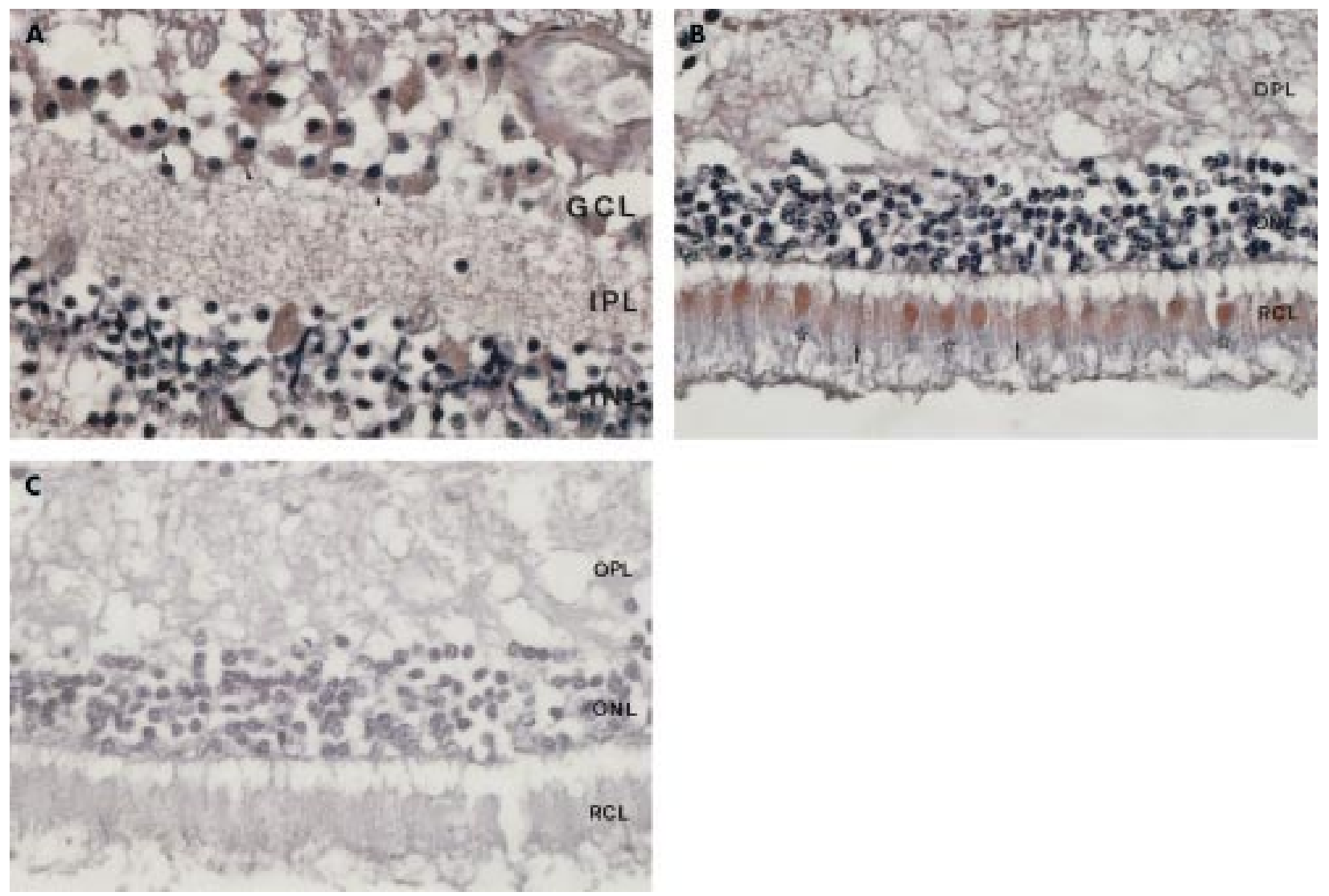

Figure 1 Immunohistochemical staining of MT1 receptors in the retinal ganglion cell layer (arrowheads) and in cells of the inner nuclear layer (A) and in the photoreceptor layer (rods = stars, cones = arrows) (B) of the central part of the retina. (C) represents a negative control. $R C L=$ rod and cone layer; $\mathrm{ONL}=$ outer nuclear layer; $\mathrm{OPL}=$ outer plexiform layer; $\mathrm{INL}=$ inner nuclear layer; $\mathrm{IPL}=$ inner plexiform layer; $\mathrm{GCL}=$ ganglion cell layer. Magnification: $40 \times(A) ; 20 \times(B, C)$. 

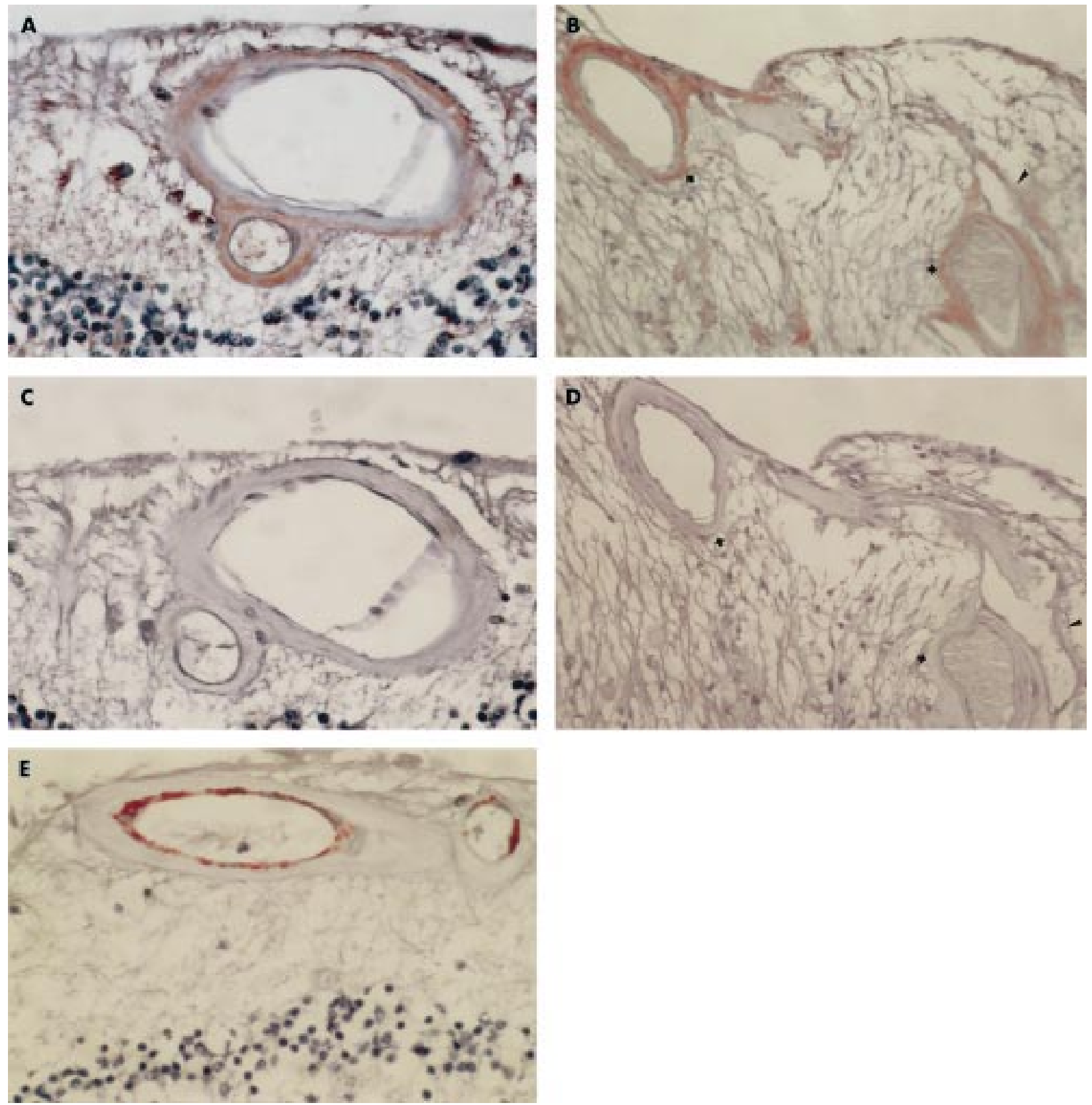

Figure 2 MTI-IR in the adventitia of retinal vessels in the ganglion cell layer and the inner plexiform layer (A), and in the central retinal artery (arrow) and vein (arrowhead) (B). (C) and (D) represent the corresponding negative controls. (E) represents the staining of the smooth muscle cells of the tunica media with a monoclonal antibody against $\alpha$-smooth muscle actin. $R C L=$ rod and cone layer; $O N L=$ outer nuclear layer; $\mathrm{OPL}=$ outer plexiform layer; $\mathrm{INL}=$ inner nuclear layer IPL = inner plexiform layer; $\mathrm{GCL}$ = ganglion cell layer. Magnification: $20 \times(\mathrm{A}-\mathrm{E})$.

\section{Cornea}

Some MTI-IR was found in the endothelial cell layer, in keratocytes, and in the epithelial cell layer (compare Fig 3, Table 3).

\section{DISCUSSION}

We detected MTl-IR primarily in the inner segments of rods and cones, retinal ganglion cells, and in a few cells of the inner nuclear layer. In addition, MTI-IR was present in the adventitia of retinal arteries and veins, predominantly in the papillary region, but was absent from ciliary and choroidal vessels. Mild staining of corneal endothelial cells and keratocytes was observed in all but two eyes.

In our study, it was most impressive that all photoreceptor cells revealed distinct MTI immunoreactivity in their inner segments. Moreover, MTI-IR extended as an immunoreactive band throughout the whole photoreceptor cell layer. Recent studies in rodents failed to demonstrate MTI-IR in photoreceptor cells. ${ }^{90}$ Using in situ hybridisation, Wiechmann and coworkers, however, demonstrated melatonin mRNA in photoreceptor segments of the frog retina. ${ }^{13}$ Therefore, interspecies differences may exist. The role of melatonin in photoreceptor function is as yet only partially disclosed. Several lines of evidence suggest that retinal melatonin is mainly synthesised in the photoreceptor cells, ${ }^{2}$ where it has been proposed to has a role as a scavenger of free radicals. ${ }^{7}$ Furthermore, it has been shown that melatonin reduces nitric oxide induced lipid peroxidation in rat retinal homogenate. ${ }^{14}$ On the other hand, melatonin was reported to mediate light damage to photoreceptor cells by an as yet unknown mechanism. ${ }^{15}{ }^{16}$ It has been suggested that melatonin may mediate inhibition of dopamine release, thus resulting in the 


\begin{tabular}{|c|c|c|c|c|}
\hline Case No & $\begin{array}{l}\text { Central } \\
\text { retinal artery }\end{array}$ & $\begin{array}{l}\text { Central } \\
\text { retinal vein }\end{array}$ & $\begin{array}{l}\text { Retinal } \\
\text { vessels }\end{array}$ & $\begin{array}{l}\text { Choroidal } \\
\text { vessels }\end{array}$ \\
\hline 1 & ++ & ++ & + & - \\
\hline 2 & +++ & +++ & +++ & - \\
\hline 3 & ++ & ++-+ & +++ & - \\
\hline 4 & ++ & +++ & ++ & + \\
\hline 5 & ++ & ++ & ++ & - \\
\hline 6 & +++ & +++ & +++ & + \\
\hline 7 & +++ & +++ & +++ & - \\
\hline
\end{tabular}

loss of neuroprotective action of dopamine on the photoreceptor cells. ${ }^{2}$ Dopamine inhibits outer segment disc shedding of photoreceptors, ${ }^{17}$ and dopamine $\mathrm{D}_{2}$-like receptors have been identified on rodent photoreceptor cells. ${ }^{18}{ }^{19}$ Melatonin and dopamine most probably act as opponents; both substances are synthesised within the retina in a circadian rhythm, but while melatonin is synthesised and released at night, dopamine synthesis and release is stimulated by light.

About $90 \%$ of the retinal ganglion cells revealed MTl-IR in their somata and dendritic processes. This is interesting in light of the recent discovery of phototransduction by retinal ganglion cells that set the circadian pacemaker, together with identification of melanopsin in ganglion cells, as a putative photoreceptor molecule..$^{20}$

In six of eight cases single amacrine cells presented MT1-IR. The slight MT1 labelling of the inner plexiform layer observed in this study might correspond to the binding sites on the dendritic processes of ganglion and amacrine cells. Our results
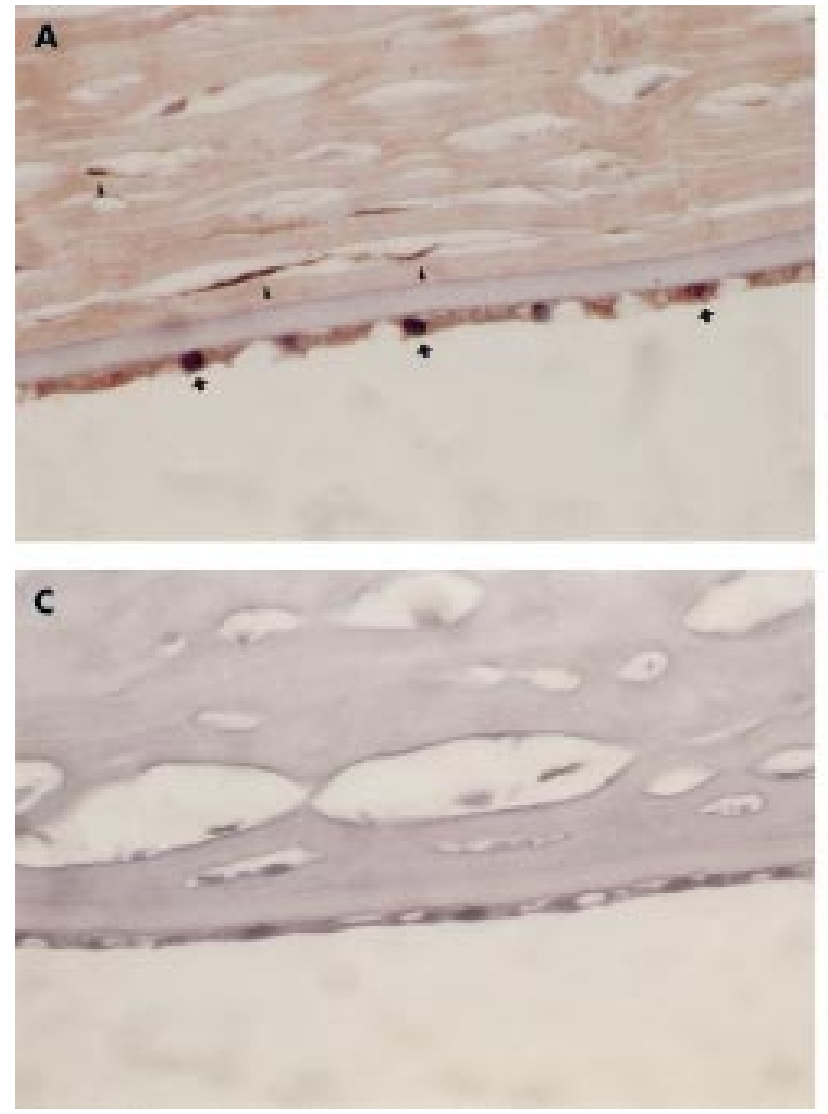

Figure 3 Immunohistochemical staining of the MTI receptor in the cornea. Endothelial cell layer (A, arrow), keratocytes (A, arrowheads) and epithelial cell layer (B, arrow). (C) and (D) represent the corresponding negative controls. Magnification: 40x: A-D.
Table 3 Intensity of specific immunoreactivity on a semiquantitative scale of $+/+++$ for corneal endothelial cells, keratocytes, and corneal epithelial cells

\begin{tabular}{llll}
\hline Case No & $\begin{array}{l}\text { Corneal } \\
\text { endothelial cells }\end{array}$ & Keratocytes & $\begin{array}{l}\text { Corneal } \\
\text { epithelial cells }\end{array}$ \\
\hline 1 & - & - & ++ \\
2 & ++ & ++ & ++ \\
3 & + & - & ++ \\
4 & + & + & + \\
5 & + & +- & +++ \\
6 & + & + & ++ \\
7 & + & + & - \\
\hline
\end{tabular}

are in agreement with previous findings in rodents. ${ }^{9}{ }^{10}$ In the latter study, MTl positive amacrine cells have been found to be dopaminergic and GABAergic. As a consequence, modulation of dopamine release by melatonin via enhancement of GABA activity was hypothesised.

We also found distinct MTI-IR in central retinal arteries and veins and also in small retinal vessels located in the ganglion cell layer and in the inner plexiform layer.

In two of six cases, we observed low levels of MTl-IR in choroidal vessels, mainly in the peripapillary region. Ciliary vessels, however, were not labelled. MTI-IR of the retinal vessels was localised to the adventitia of the vessel walls, corresponding to our previous findings in human cerebral vessels. $^{12}$ MTl receptors are supposed to mediate vasoconstriction. ${ }^{22}$ Our observation suggests that melatonin exerts its effect, if any, on retinal vascular smooth muscle in an indirect way.
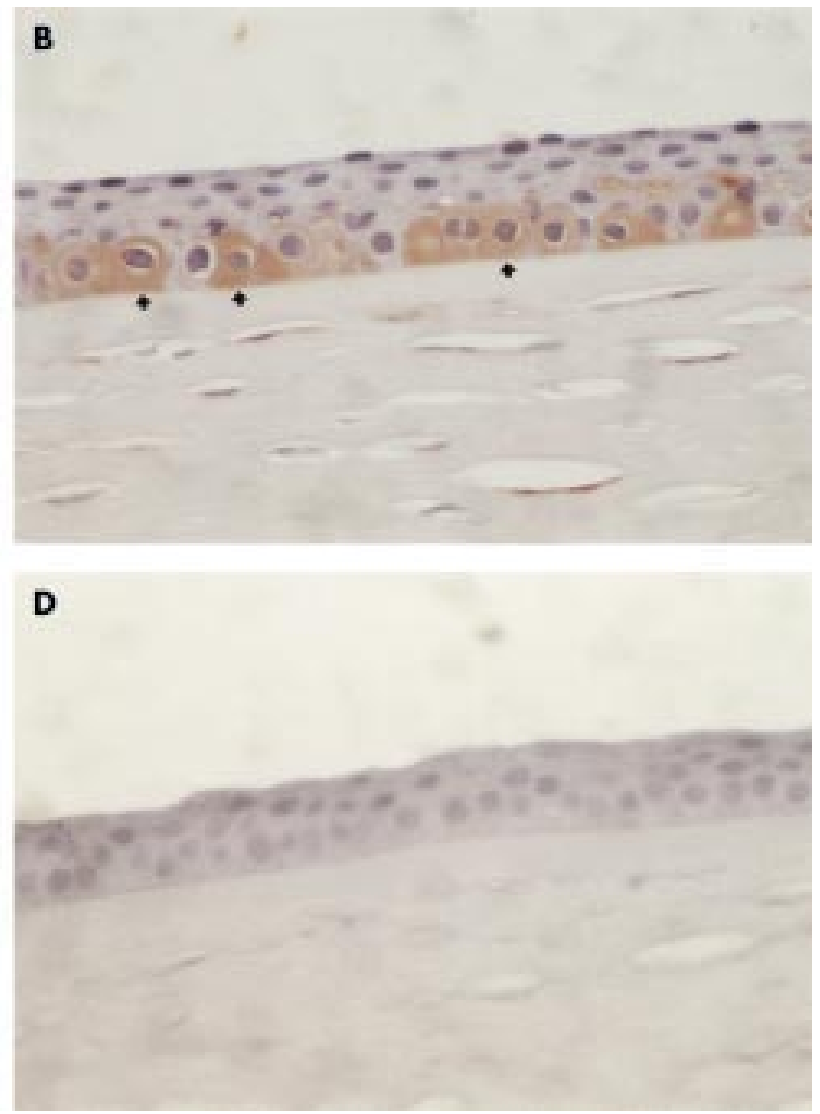
In addition, we observed mild staining of corneal endothelial cells, keratocytes, and corneal epithelial cells. Previous animal studies led to the conclusion that retinal melatonin is not involved in the generation of the corneal mitotic rhythm. ${ }^{23}$ In these studies, however, retinal photoreceptors were supposed to be the only source of ocular melatonin. Japanese quail eyes were treated with formoguanamine hydrochloride (FG), which induces photoreceptor degeneration. The fact that the corneal mitotic rhythm was maintained despite FG treatment led the authors to the conclusion that melatonin was not involved in the corneal mitotic rhythm. More recently, it has become evident that melatonin is not only synthesised by the pineal gland and by the retina, but also in various other tissues, including leucocytes, platelets, endothelial cells, ${ }^{25}{ }^{26}$ and skin cultures. ${ }^{27}$ This led us to speculate that melatonin of non-retinal origin might be involved in the circadian mitotic rhythm of the cornea, possibly via activation of the MTl receptors identified in the cornea.

However, our study has some limitations that need to be discussed. Firstly, we examined only eyes of older individuals, and therefore cannot exclude changes with age such as, for example, a downregulation of melatonin receptors with increasing age as described in an animal model. ${ }^{28}$ Secondly, the majority of the examined eyes originated from postmenopausal females. It is known that female reproductive hormones modulate the expression of vascular melatonin receptors in the rat. ${ }^{29}$ Therefore, our results may be somewhat different in men and premenopausal women. Furthermore, even though we found positive MTI-IR in the adventitia of the retinal vessels, we cannot completely exclude some diffusion of the label from one layer to the next in our postmortem eyes. Therefore, also MTl-IR of the smooth muscle cell layer might be present in our cases. On the other hand, we performed $\alpha$-smooth muscle actin staining in adjacent sections using specific monoclonal antibodies. $\alpha$-Smooth muscle actin stained the tunica media in all sections, thereby indicating that MTI-IR is present in the adventitia and not in the muscular layer.

Future studies should address this critical issues. Preliminary data also indicate that the distribution of MTl receptors is altered in patients with neurodegenerative diseases like Alzheimer's disease (unpublished data).

The highly selective immunostaining of retinal arteries and veins implies a possible role for melatonin in retinal vessel function and also warrants further investigation.

\section{ACKNOWLEDGEMENTS}

The authors thank Miriam Vonlanten for her technical assistance.

Lena Brydon and Ralf Jockers were supported by grants from the CNRS, the Université Paris VII, the Association pour la Recherche sur le Cancer (ACR No 513).

\section{Authors' affiliations}

P Meyer, M Pache, J Flammer, University Eye Clinic, Basle,

Switzerland

A Wirz-Justice, E Savaskan, Department of Gerontopsychiatry, Center for Chronobiology, Basle, Switzerland

L Brydon, R Jockers, Institut Cochin de Génétique Moléculaire, Paris, France

K U Loeffler, University Eye Clinic, Bonn, Germany

\section{REFERENCES}

1 Wiechmann AF, Hollyfield JG. HIOMT-like immunoreactivity in the vertebrate retina: a species comparison. Exp Eye Res 1989;49:107995 .
2 Tosini G. Melatonin circadian rhythm in the retina of mammals. Chronobiol Int 2000;17:599-612.

3 Pierce ME, Besharse JC. Circadian regulation of retinomotor movements 1. Interaction of melatonin and dopamine in the control of cone length. $J$ Gen Physiol 1985;86:671-89.

4 White MP, Fisher LJ. Effects of exogenous melatonin on circadian disc shedding in the albino rat retina. Vis Res 1989;29:167-79.

5 Wiechmann AF, Yang XL, Wu SM, et al. Melatonin enhances horizontal cell sensitivity in salamander retina. Brain Res 1988;453:377-80.

6 Dubocovich ML. Melatonin is a potent modulator of dopamine release in the retina. Nature 1983;306:782-4.

7 Marchiafava PL, Longoni B. Melatonin as an antioxidant in retinal photoreceptors. J Pineal Res 1999;26:184-9.

8 Brydon L, Barrett P, Morgan PJ, et al. Investigation of the human Mel 10 melatonin receptor using anti-receptor antibodies. Adv Exp Med Bio 1999:460:215-20.

9 Fujieda $\mathrm{H}$, Scher J, Hamadanizadeh SA, et al. Dopaminergic and GABAergic amacrine cells are direct targets of melatonin: immunocytochemical study of $\mathrm{mtl}$ melatonin receptor in guinea pig retina. Vis Neurosci 2000;17:63-70.

10 Fujieda $\mathbf{H}$, Hamadanizadeh SA, Wankiewicz E, et al. Expression of MT1 melatonin receptor in rat retina: evidence for multiple cell targets for melatonin. Neuroscience 1999;93:793-9.

11 Olivieri G, Miescher GC. Immunohistochemical localization of EphA5 in the adult human central nervous system. J Histochem Cytochem 1999;47:855-61

12 Savaskan E, Olivieri G, Brydon L, et al. Cerebrovascular melatonin MT1-receptor alterations in patients with Alzheimer's disease. Neurosci Lett 2001;308:9-12.

13 Wiechmann AF, Smith AR. Melatonin receptor RNA is expressed in photoreceptors and displays a diurnal rhythm in Xenopus retina. Brain Res Mol Brain Res 2001;91:104-11.

14 Siu AW, Reiter R, To $\mathrm{CH}$. Pineal indoleamines and vitamin $\mathrm{E}$ reduce nitric oxide-induced lipid peroxidation in rat retinal homogenates. J Pineal Res 1999;27: 122-8.

15 Wiechmann AF, O'Steen WK. Melatonin increases photoreceptor susceptibility to light-induced damage. Invest Ophthalmol Vis Sci 1992;33: 1894-902.

16 Sugawara T, Sieving PA, luvone PM, et al. The melatonin antagonist luzindole protects retinal photoreceptors from light damage in the rat. Invest Ophthalmol Vis Sci 1998;39:2458-65

17 Reme CE, Wirz-Justice A, Terman M. The visual input stage of the mammalian circadian pacemaking system: I. Is there a clock in the mammalian eye? J Biol Rhythms 1991;6:5-29.

18 Nguyen-Legros J, Chanut E, Versaux-Botteri C, et al. Dopamine inhibits melatonin synthesis in photoreceptor cells through a D2-like receptor subtype in the rat retina: biochemical and histochemical evidence. $J$ Neurochem 1996;67:2514-20.

19 Derouiche A, Asan E. The dopamine D2 receptor subfamily in rat retina: ultrastructural immunogold and in situ hybridization studies. Eur $\mathrm{J}$ Neurosci 1999;11:1391-402.

20 Hattar S, Liao HW, Takao M, et al. Melanopsin-containing retinal ganglion cells: architecture, projections, and intrinsic photosensitivity. Science 2002;295: 1065-70.

21 Berson DM, Dunn FA, Takao M. Phototransduction by retinal ganglion cells that set the circadian clock. Science 2002;295: 1070-3.

22 Doolen S, Krause DN, Dubocovich ML, et al. Melatonin mediates two distinct responses in vascular smooth muscle. Eur J Pharmacol 1998;345:67-9.

23 Oishi T, Mohri Y, Kaneko T, et al. Retinal melatonin is not involved in corneal mitotic rhythms in the Japanese quail: effects of formoguanamine hydrochloride and eye-lid suture. J Pineal Res 1996;21:149-54.

24 Sasaki M, Masuda A, Oishi T. Circadian rhythms of corneal mitotic rate, retinal melatonin and immunoreactive visual pigments, and the effects of melatonin on the rhythms in the Japanese quail. J Comp Physiol [A] 1995; 176:465-71.

25 Finocchiaro LM, Nahmod VE, Launay JM. Melatonin biosynthesis and metabolism in peripheral blood mononuclear leucocytes. Biochem J 1991;280:727-31.

26 Kvetnoy IM. Extrapineal melatonin: location and role within diffuse neuroendocrine system. Histochem J 1999:31:1-12.

27 Slominski A, Baker J, Rosano TG, et al. Metabolism of serotonin to $\mathrm{N}$-acetylserotonin, melatonin, and 5-methoxytryptamine in hamster skin culture. J Biol Chem 1996;271:12281-6.

28 Laitinen JT, Viswanathan M, Vakkuri O, et al. Differential regulation of the rat melatonin receptors: selective age-associated decline and lack of melatonin-induced changes. Endocrinology 1992;130:2139-44.

29 Seltzer A, Viswanathan M, Saavedra JM. Melatonin-binding sites in brain and caudal arteries of the female rat during the estrous cycle and after estrogen administration. Endocrinology 1992;130: 1896-902. 